DOI 10.37882/2500-3682.2021.08.18

\title{
МНОЖЕСТВЕННАЯ СУБЪЕКТИВНОСТЬ И ПРОБЛЕМЫ ТЕХНОГЕННОЙ ЦИВИЛИЗАЦИИ
}

\section{MULTIPLE SUBJECTIVITY AND THE PROBLEMS OF TECHNOGENIC CIVILIZATION}

M. Openkov N. Tetenkov

Summary: The object of the study is multiple subjectivity and technogenic civilization The purpose of the study is to consider the question whether technology is a rock for a person. The relevance and novelty lies in the fact that the authors for the first time consider the perception of technology by multiple subjectivity. The theoretical basis of the article is the works of Pico della Mirandola, Yates, where the idea of human uncertainty is expressed, in the works of Ixkull, Vollmer, etc., which consider the cognitive capabilities of a person, M. Heidegger's views on technology and the attitude of a person to technology. The hypothesis of the article is that due to the multiple subjectivity inherent in a person, a technogenic civilization is not fatal for a person. The methodological basis of the article is the analysis of the concepts of «multiple subjectivity» and "cognitive niche», the analysis of the relationship of multiple subjectivity to technology.

Keywords: multiple subjectivity, cognitive niche, technogenic civilization, Heidegger, Pico della Mirandola, Vollmer.
Опёнков Михаил Юрьевич

Д.ф.н., профессор, Северный (Арктический) федеральный университет имени М.В. Ломоносова, Архангельск kotobarz@gmail.com

тетенков Николай Борисович

К.ф.н., дочент, Северный (Арктический) федеральный университет имени М.В. Ломоносова, Архангельск tenibo@yandex.ru

Аннотация: Объектом исследования являются множественная субъективность и техногенная цивилизация Цель исследования - рассмотреть вопрос, является ли техника роком для человека. Актуальность и новизна заключается в том, что авторы впервые рассматривают восприятие техники множественной субъективностью. Теоретическую основу статьи составляют работы Пико делла Мирандолы, Йейтса, где высказывается идея 0 неопределённости человека, в работах Икскюля, Фоллмера и т.д., в которых рассматриваются когнитивные возможности человека, взгляды М. Хайдеггера на технику и отношение человека к технике. Гипотеза статьи - в силу множественной субъективности, присущей человеку, техногенная цивилизация не является фатальной для человека. Методологической основой статьи является анализ понятий «множественная субъективность» и «когнитивная ниша», анализ отношения множественной субъективности к технике.

Ключевые слова: множественная субъективность, когнитивная ниша, техногенная цивилизация, Хайдеггер, Пико делла Мирандола, Фоллмер.

Находясь в Падуанском университете Пико сближается с каббалистами.

Флавий Митридат переводит для него каббалистические комментарии к «Книге творения». «Девятьсот тезисов» Пико делла Мирандолы - это манифест, который обращен только к тем философам и теологам, которых Пико считал правильными и настоящими. Среди них схоласты, неоплатоники и те каббалисты, которые готовы признать, что из Каббалы с необходимостью выводится истинность христианства. Именно они должны были, по замыслу Пико, сформировать некое философско-теологическое единство и высказаться по поводу самых разнообразных вопросов, положив конец спорам [1].

Необходимо отметить промежуточное положение Пико между Каббалой и «Великим искусством» Раймунда Луллия.

Пико прекрасно сознавал, что отличие каббалистической мысли от луллианской состоит в том, что каббалист неизвестную реальность открывает посредством чтения по слогам переставляемых букв. Луллианская комбинаторика не открывает неизвестной реальности, она рабо- 
тает с уже с известной и никоим образом не меняет её.

Одним из источников Луллия можно считать идею Великой Цепи Бытия. Эта идея является по своему происхождению неоплатонической. Строгий неоплатонизм, который Средневековье принимает умеренно, утверждает, что Божественная Вселенная - это эманация непознаваемого и неописуемого Единого через ряд ступеней бытия или ипостасей, продуцирующих на различных уровнях вплоть до самой низшей материи.

Существа размещаются на ступенях, последовательно удаляясь от Единого и принимая по убыванию участие в Божественной природе, которая умаляется, рассеиваясь до низших ступеней цепи или лестницы сущностей. Отсюда берут начало два принципа - космологический и этико-мистический.

Каббала, принятая в Средневековой Испании, проповедовала учение о 10 сефирот и 22 буквах еврейского алфавита. Сефирот - это 10 имён Бога, образующие вместе одно великое Имя. Мироздание есть проявление этих творящих имён.

Соответственно, 10 имён сефирот коррелировали с 10 сферами космоса: 7 сфер планет, сфера звёзд, и 2 высшие сферы. В качестве метода прочтения Каббалы использовалась гематрия, согласно которой каждой букве еврейского алфавита соответствовало число. Предполагалось, что транспортируя слова в числа, а числа слова, можно познать мироздание, которое записано этими числами-словами, например, небесное воинство, с этой точки зрения, определялось числом 301655172.

Слова-числа ассоциировались и с именами 72 Ангелов, которых можно призвать и благодаря им получить доступ с сефирот, призвать Ангелов можно было только на еврейском языке или молчаливым призыванием при помощи демонстрации букв, слов или знаков.

Согласно космологическому принципу, если каждая ступень лестницы бытия - это фаза одной и той же Божественной эманации, то существуют отношения сходства, родственности и аналогии между низшими и высшими состояниями. Именно эта идея лежит в основе всех теорий сходства и космической симпатии.

Согласно этико-мистическому принципу, если эманационная лестница представляет собой нисхождение от непостижимого совершенства Единого к низшим ступеням материи, то познание, спасение и мистический союз подразумевают восхождение, возвращение к высшим состояниям Великой Цепи Бытия.

Луллий создал механизм, который рассматривал не только вопросы теологии и метафизики, но и космологии, геометрии, медицины и т.д., тем самым Ars стал механизмом создания энциклопедии знания.
Ars выстраивает вопросы также по принципу иерархии (существует ли что-то, что это, каким способом существует и т.д.), иерархически выстраиваются и субъекты: Бог, ангелы, небо и т.д. Ars позволяет осмыслить элементы лестницы, Вселенной, возможные вопросы. Древо Знания является образом лестницы, корни Древа - 9 достоинств и 9 отношений, у него 16 ветвей, из которых вырастает своё древо.

Исследователи отмечают в древах динамичность, почти биологического типа, контрастирующую с логикоматематической статичностью луллианского искусства предшествующего периода, но чтобы уметь пользоваться Искусством, предполагается предварительное знание, которое как раз допускается древами [2].

Следуя хитрым советам Флавия Митридата, нежели тех, кто предлагал факториальное исчисление, начиная с Пико утверждался - в соответствии с его идеей защиты достоинства и прав человека - призыв к изобретению. Это означает, что если мы говорим о бытии, то следует избрать то бытие, которое еще должно быть создано, а не то, которое уже существует. Пико подтолкнул современную мысль в этом направлении.

«Речь о достоинстве человека» можно с полным правом назвать Великой хартией магии Возрождения - новой магии, созданной Фичино и усовершенствованной Пико делла Мирандола [3]. В ней он отмечал: «Рождающемуся человеку Отец дал семена и зародыши разнородной жизни и соответственно тому, как каждый их возделает, они вырастут и дадут в нем свои плоды. И если зародыши растительные, то человек будет растением, если чувственные, то станет животным, если рациональные, то сделается небесным существом, а если интеллектуальные, то станет ангелом и сыном Бога. А если его не удовлетворит судьба ни одного из творений, то пусть возвратится к центру своего единообразия и, став единым с Богом-духом, пусть превосходит всех в уединенной мгле Отца, который стоит над всем. И как не удивляться нашему хамелеонству!» [4].

Значит, человек есть творение неопределенного облика или существо-хамелеон. На какие мысли это наводит?

В работе «A Stroll Through the Worlds of Animals and Men» фон Икскюль значении использовал понятие «окружающий мир», которое мы можем трактовать как «когнитивная ниша», и охарактеризовал окружающие миры насекомых и животных [5]. На основании приведённых примеров фон Икскюль сделал вывод, что для любого организма свойственен свой окружающий мир или когнитивная ниша. Продолжая мысль фон Икскюля, Фоллмер Г. отмечал: «Когнитивную нишу человека мы называем «мезокосмос». Наш мезокосмос есть, таким образом, часть реального мира, которым мы овладеваем, воспринимая и действуя, сенсорно и моторно. Мезокос- 
мос - грубо говоря - мир средних размеров» [6].

Исходя из сказанного выше можно сделать выводы:

1. У человека нет собственной когнитивной ниши. Есть существа, которые в своей когнитивной нише гораздо эффективнее человека. Наш разум состоит из множества когнитивных ниш. Наш разум заключается в пересечении границ между когнитивными и нишами. Наше сознание множественно. Потенциально мы - носители множественной субъективности.

2. Введенное Герхардом Фоллмером понятие «мезокосмос» - типичный пример ретросказания. Ведь мезокосмос уже продуман теоретически. Это мир геометрии Евклида (плоская земля) и физики Аристотеля (движение исключительно в упругих средах). Можно согласиться с Фоллмером лишь в том, что наука есть выход за пределы очевидного.

3. Необходимо ввести понятие расслоения (bundle) в истории мысли.

Первый пример такого расслоения - наследие Пико делла Мирандолы. Расслоение возникает тогда, когда философ обозначает расходящиеся тропы мысли. Таков Мирандола. Он стоит у начала двух дорог. Одна и них дорога европейского гуманизма, которая привела к техногенной цивилизации, другая приводит к теории множественной субъективности. Европейская цивилизация выбрала технический путь развития, оставляя множественную субъективность маргиналам, ранее принадлежавшим к богемной периферии общества. Например, dandy. Итальянский философ-марксист, футуролог и медиа-активист Франко «Бифо» Берарди также обращается к наследию Пико делла Мирандолы. Свое рассуждение о достоинстве человека Пико делла Мирандола сочинял в конце XV века, когда приоткрылся горизонт современности и начался процесс распространения технического и промышленного могущества. Пико говорил, что величие человека не подкреплено никаким архетипом, никакой нормой, никакой необходимостью. Ведь Творец никак не конкретизировал путь, по которому призвано следовать человеческое могущество. Настоящим постулатом открывается эпоха современности: человек представляет собой не развитие и не осуществление заранее предначертанного плана, таящегося в Божественном произволении или же в складках Бытия. Человек - это проект. Из этих пустот Бытия и рождается история современности.

Ницшеанская воля к власти рождается уже в лоне радикального гуманизма. Его предпосылка - отсутствие онтологических определений человеческого существования.

Отказ от онтологии во имя герменевтики приводит к тому, что фундаментальные истины сменяются вольной игрой интерпретаций. Человек это не конкретизация чего-то, а воплощение проективности. Ницшеанский сверхчеловек тот, кому удается действовать в лишенном каких-либо основ пространстве, и в этом смысле он находится по ту сторону добра и зла. То, что Ницше именовал волей к власти, на самом деле представляет собой проективность, прокладывающую себе путь в мире исходя и производства смыслов, не имеющего под собой никакого онтологического основания и сугубо интенционального. Воля к власти означает утверждение некоего закона, который не имеет никаких иных предпосылок, кроме свободы интерпретаций.

В современном понимании, сверхчеловек - продукт математизации познания, оцифровки знания и автоматизации всей жизни. Язык это обиталище Бытия; в то же время, как предупреждает Хайдеггер, язык принадлежит к области техники. Техника не только становится приоритетным объектом языка, но и субъектом, который нечто производит, высказывает и проектирует.

Хайдеггер начинает с того, что в нынешних условиях мир превращается в картину мира. Именно в этом заключается предпосылка завоевания мира и подчинения его себе. Данный процесс осуществляется настолько быстро, что заинтересованные лица даже не отдают себе отчета в происходящем.

Кто такие эти заинтересованные лица, эти участники бега? Это люди, отстраняемые мало-помалу от управления миром. Их место занимают автоматизмы, которые внедряются в мир и переделывают его. По утверждению Хайдеггера, люди не в состоянии оценить той непреклонности, с какой современный мир движется к истощению его собственной сущности. Истощение представляет собой неведение, зависимость людей от власти механизмов. Люди все менее способны разобраться в феноменах, которые ими самими были приведены в действие. Благодаря их свободе, порожденной дистанцией между человеком и Бытием, а также онтологической непредвзятостью существования, людям удалось выстроить такую техническую сферу, которая внедрилась в одну из пустот Бытия. Пустота Бытия оказалась заполненной перформативным потенциалом техносферы; цифровой условностью, которая преобразуется в эффективный механизм. Конец гуманизма предопределен его же собственным высоким потенциалом.

Вопрос в том, не является ли то, что представляется нам детерминизмом (порожденным знанием и техникой в сфере существования), на самом деле всего лишь новым уровнем (более высоким и утонченным) неопределенности, присущей любой сложной системе?

Согласно Хайдеггеру, техника - это бытийная нужда человека. Сущность техники коренится не в человеке, а в бытии, но если это так, то от власти техники никак не избавится. Это рок и судьба человека, это путь европейского гуманизма. Если же субъективность множе- 
ственна, то много других, незаполненных пустот бытия. Кризисные периоды в развитии цивилизации (фазовые барьеры) способствуют переключению регистров мышления. Человеческое мышление должно овладеть искусством протекания песка сквозь пальцы.

А кроме того: «В доме Отца Моего обителей много, а если бы не так, Я сказал бы вам: «Я иду приготовить место вам...».

Есть одна странная аналогия, которая очень заинтересовала бы Пикко делла Мирандолу, будь он сейчас с нами.

После изгнания из Эдема Адам и Ева осознали последствия совершённого греха. В молитве Богу Адам извинился за то, что нарушил запрет Бога и вкусил плоды Древа Познания. Бог внял молитве Адама и послал архангела Разиэля, чтобы он научил Адама законам природы, знания, переданные Разиэлем Адаму, должны помочь людям вернуться в Эдем. В числе переданных Разиэлем Адаму знаний были знания власти слова и энергии, заключённых в буквах еврейского алфавита, значениям имён и т.д., которые должны были помочь Адаму гармонизировать его жизнь в физическом мире. Согласно легенде, письмо Разиэля Адамы было высечено на стеле из сапфира.

Письмо было украдено и брошено в морскую пучину херувивами, которые не желали, чтобы Адам обладал этими знаниями, но Бог повелел ангелу Рехабу поднять его и вернуть Адаму. Далее письмо Разиэля оказалось у Ноя, патриарха Авраама, Моисея и далее передано царю Соломону.

Обратим внимания на сапфировый носитель абсолютного знания. Сапфир по твёрдости уступает только алмазу, а по прочим характеристикам, годным для хранения информации, даже кое-в чём превосходит алмаз.
Французская организация ANDRA и компания под названием Fahrenheit 2451, занимающиеся утилизацией радиоактивных отходов, озадачились вопросом сохранности информации на сроки, которые тяжело представить любому человеку - тысячи и сотни тысяч лет.

Современные носители, такие как флэш-память, жёсткие и оптические диски не справляются с этой задачей: они быстро сгнивают, а задача заключается в том, чтобы сохранять информацию о радиоактивных отходах на максимально долгий срок и передать её в будущему человечеству, предупредив его об опасности. Таким возможным носителем информации может быть сапфировые диски диаметром 20 см. Сначала информация гравируется на металлизированном покрытии одного диска, а затем второй диск сращиваются вместе на молекулярном уровне. По сути, это аналоговый способ хранения, но, по прошествии веков, становится ясно, что нет надежнее бумаги, фотопленки и, наконец, камня.

По утверждению разработчиков, на сапфировом диске можно хранить до 40000 страниц, только для их прочтения нужен будет микроскоп, этот диск может просуществовать примерно 10 млн. лет и выдерживает нагревание до $2000 \mathrm{C}^{\circ}$. Сапфировые диски можно уронить на дно Северного Ледовитого Океана, их можно отправить на Луну. Но самое главное в изобретении - это то, что для чтения сапфировых дисков практически не нужно переделывать инфраструктуру уже существующих считывающих / воспроизводящих устройств. Разве что легкая модернизация, несложный и недорогой апгрейд, возможно на уровне софта. Можно записать на сапфировый диск любую информацию: 2700 фотографий и 10000 страниц печатного текста миниатюрным средневековым шрифтом «минускула».

Сапфировый носитель памяти можно назвать метафорически подарком архангела Разиэля.

\section{ЛИТЕРАТУРА}

1. Пико делла Мирандола Джованни. Девятьсот тезисов. Тезисы 1-400. Четыреста суждений по учениям халдеев, арабов, евреев, греков, египтян и по мнениям латинян. СПб.: Изд-во Русской христианской гуманитарной академии, 2010, с.11-23

2. Эко У. От древа к лабиринту. Исторические исследования знака и интерпретации. М.: Академический проект, 2016, с.381-394

3. Йейтс, Ф.А. Джордано Бруно и герметическая традиция. М.: Новое литературное обозрение, 2020, с.103-104

4. Пико делла Мирандола Джованни Речь о достоинстве человека // http://platonizm.ru/content/piko-della-mirandola-rech-o-dostoinstve-cheloveka

5. Jakob von Uexküll, A Stroll Through the Worlds of Animals and Men: A Picture Book of Invisible Worlds. In Instinctive Behavior: The Development of a Modern Concept, edited and translated by Claire H. Schiller, New York: International Universities Press, 1957, pp. 5-80.

6. Фоллмер Г. Мезокосмос и объективное познание (о проблемах, которые решены эволюционной теорией познания) // Вест. Моск. ун-та. сер. 7, философия. 1994. № 6

7. Берарди Франко «Бифо». Душа за работой. От отчуждения к автономии. М.: 000 «Издательство Грюндриссе», 2019, с.271-277

○ Опёнков Михаил Юрьевич (kotobarz@gmail.com), Тетенков Николай Борисович (tenibo@yandex.ru).

Журнал «Современная наука: актуальные проблемы теории и практики» 